\title{
Androgen Receptors in the Posterior Bed Nucleus of the Stria Terminalis Increase Neuropeptide Expression and the Stress-Induced Activation of the Paraventricular Nucleus of the Hypothalamus
}

\author{
Brenda Bingham', Clara Myung', Leyla Innala', Megan Gray', Adam Anonuevo' and Victor Viau*,' \\ 'Neuroscience Program, Department of Cellular and Physiological Sciences, Life Sciences Centre, The University of British Columbia, Vancouver, \\ $B C$, Canada
}

\begin{abstract}
The posterior bed nuclei of the stria terminalis (BST) are important neural substrate for relaying limbic influences to the paraventricular nucleus (PVN) of the hypothalamus to inhibit hypothalamic-pituitary-adrenal (HPA) axis responses to emotional stress. Androgen receptor-expressing cells within the posterior BST have been identified as projecting to the PVN region. To test a role for androgen receptors in the posterior BST to inhibit PVN motor neurons, we compared the effects of the non-aromatizable androgen dihydrotestosterone (DHT), the androgen receptor antagonist hydroxyflutamide (HF), or a combination of both drugs implanted unilaterally within the posterior BST. Rats bearing unilateral implants were analyzed for PVN Fos induction in response to acute-restraint stress and relative levels of corticotrophin-releasing hormone and arginine vasopressin (AVP) mRNA. Glutamic acid decarboxylase (GAD) 65 and GAD 67 mRNA were analyzed in the posterior BST to test a local involvement of GABA. There were no changes in GAD expression to support a GABA-related mechanism in the BST. For PVN neuropeptide expression and Fos responses, basic effects were lateralized to the sides of the PVN ipsilateral to the implants. However, opposite to our expectations of an inhibitory influence of androgen receptors in the posterior BST, PVN AVP mRNA and stress-induced Fos were augmented in response to DHT and attenuated in response to HF. These results suggest that a subset of androgen receptor-expressing cells within the posterior BST region may be responsible for increasing the biosynthetic capacity and stress-induced drive of PVN motor neurons.

Neuropsychopharmacology (20 II) 36, I433-1443; doi:I0.1038/npp.20 I I.27; published online I6 March 20 I I
\end{abstract}

Keywords: androgens; HPA axis; posterior bed nucleus of the stria terminalis; flutamide; dihydrotestosterone

\section{INTRODUCTION}

The hypothalamic-pituitary-adrenal (HPA) axis represents a chain of sequentially released hormones from the brain to the periphery that regulates glucocorticoid release from the adrenal (cortisol in human beings, corticosterone in the rat). Elevations in circulating glucocorticoids provide a front line of defense against threats to homeostasis (ie, stress) by mobilizing energy stores in the body to facilitate appropriate autonomic, neuroendocrine, and behavioral responses. Stress activates the HPA axis by initiating the recruitment of neurosecretory neurons in the paraventricular

*Correspondence: Dr V Viau, Neuroscience Program, Department of Cellular and Physiological Sciences, Life Sciences Centre, The University of British Columbia, 2350 Health Sciences Mall, Vancouver, BC, Canada V6T IZ3, Tel: + I 604822 3899, Fax: + | 6048222316

E-mail: viau@interchange.ubc.ca

Received 9 October 2010; revised 24 January 2011; accepted 10 February 2011 nucleus (PVN) of the hypothalamus to secrete peptide stores from the median eminence, including corticotropinreleasing hormone (CRH) and arginine vasopressin (AVP). Taken together, these neuropeptides synergize on the release of adrenocorticotropin hormone (ACTH) from the anterior pituitary to regulate the synthesis and release of glucocorticoids from the adrenal cortex.

Stress can have positive or negative effects on sex steroid hormone secretion (Gomez et al, 2004; Rivier and Rivest, 1991; Sapolsky, 1986). Conversely, the magnitude of the HPA response to stress also varies as a function of gonadal status. In male rats, testosterone inhibits ACTH and glucocorticoid release, as well as the stress-induced activation of PVN motor neurons (Handa et al, 1994; Viau et al, 2003; Viau and Meaney, 1991). Likewise, testosterone and its metabolites introduced into the vicinity of the PVN and in the medial preoptic nucleus inhibit HPA axis responses (Lund et al, 2006; Viau and Meaney, 1996; Williamson et al, 2010). 
However, several additional forebrain and hypothalamic structures that project to the $\mathrm{PVN}$ and/or regulate $\mathrm{ACTH}$ release also contain a high number of sex steroid hormone receptors (Williamson and Viau, 2007). This suggests that there is likely a complex network dedicated to the central actions of testosterone on HPA axis responses. Determining the neurocircuitry and mechanisms by which testosterone acts in the brain to modulate HPA function is crucial for understanding individual and sex-based differences in susceptibility to stress-related disorders.

In contrast to nuclei supplying sensory information to the HPA axis, limbic-emotional pathways to the PVN are indirect and rely upon various forebrain and hypothalamic relays, including the bed nuclei of the stria terminalis (BST) (Cullinan et al, 1993; Dong and Swanson, 2004; Gu et al, 2003; Sawchenko and Swanson, 1983). Lesions studies suggest that cells occupying the posterior division of the BST inhibit PVN and HPA responses, likely provided by GABAergic inputs (Choi et al, 2007). The posterior BST contains one of the highest densities of sex steroid hormone receptors in the forebrain (Shughrue et al, 1997; Simerly, 1993), and a significant complement of PVN-projecting cells in this region contain the androgen receptor (Williamson and Viau, 2007). Furthermore, the posterior BST also sends projections back to the amygdalar and lateral septal nuclei, both of which are putative regulators of the HPA axis. Collectively, these findings implicate the posterior BST as an important site of interaction between sex steroid hormone and limbic influences on the HPA axis.

The posterior BST is sexually dimorphic, with male rats showing a greater numbers of cells and higher projection densities compared with female rats (de Vries, 2008). Testosterone exposure during the perinatal period has been shown in adult male rats to increase the size and number of cells in the principle nucleus of the posterior BST (Guillamon et al, 1988). Moreover, the inhibitory effect of neonatal testosterone on adult PVN and HPA responses to stress is associated with increased numbers of androgen receptors in the posterior BST (Bingham and Viau, 2008).

On the basis of these findings, we previously proposed that androgen receptors in the posterior BST could contribute to the upstream influences of testosterone on the PVN and its extended circuitries (Bingham et al, 2006; Bingham and Viau, 2008). To test this hypothesis, in this study we measured neuropeptide expression levels under basal conditions and Fos responses to acute restraint stress in PVN, lateral septum, and amygdalar nuclei in male rats bearing discrete unilateral implants of androgen steroid and/or antagonist into the posterior BST region. As GABA neurotransmission is sensitive to androgens and plays a significant role in limbic regulation of the PVN, we also assessed glutamic acid decarboxylase (GAD) expression in the posterior BST. Unilateral implants were chosen over a bilateral approach to take advantage of the unilateral projection profiles of the posterior BST and to avoid possible secondary effects attributed to alterations in adrenal corticosteroid responses. PVN responses to stress vary as a function of testosterone levels in circulation (Viau et al, 2003). Thus, to credit drug effects primarily to changes in androgen receptor occupancy in the posterior BST, we superimposed castration plus low physiological levels of testosterone replacement.

\section{MATERIALS AND METHODS}

\section{Animals}

Fifty-eight adult male Sprague-Dawley rats (Harlan Laboratories, Indianapolis, IN) were used. Animals were pair-housed under controlled temperature and lighting conditions $(12 \mathrm{~h}$ light/dark schedule, lights on at 0700 hours), with food (Rad diet 5012, Lab Diet) and water available ad libitum. Animals were subjected to experimental procedures at 70 days of age, and then handled daily until testing. All experimental protocols were approved by the University of British Columbia Animal Care Committee.

\section{Adult Testosterone Replacement}

To reveal a dependency of PVN neurons on androgen receptors in the posterior BST, animals were castrated at 70 days of age and implanted with subcutaneous capsules designed to deliver stable concentrations of testosterone in circulation. Testes were removed under isoflurane anesthesia, during which animals received a single subcutaneous Silastic capsule (inner diameter $1.57 \mathrm{~mm}$, outer diameter $3.18 \mathrm{~mm}$, length $7.5 \mathrm{~mm}$ ), packed with crystalline testosterone. The size of this capsule produces stable, physiological levels of testosterone in the order of $0.5 \mathrm{ng} / \mathrm{ml}$ (Williamson and Viau, 2008). This level of testosterone replacement was chosen to detect effects mediated by local changes in androgen receptor signaling in the posterior BST while sustaining low background levels of androgen receptor occupancy within other brain regions.

\section{Intracerebral Microimplants}

At 1 week after testes removal and testosterone replacement, animals received stereotaxically guided, unilateral microimplants of the non-aromatizable androgen dihydrotestosterone (DHT; Sigma Chemicals, Oakville, ON, Canada), the androgen receptor antagonist hydroxyflutamide (HF; Toronto Research Chemicals, North York, ON, Canada), or a mixture of both drugs under isoflurane anesthesia. Twenty-two-gauge cannula ejectors were aimed to terminate within the centrolateral part of the posterior division of the BST, biased towards the medial border of the descending limb of the internal capsule. The coordinates chosen (see below) were designed to target the major androgen receptor-containing nuclei of the posterior BST, but aimed far enough to be removed from the medial zone of the hypothalamus to avoid drug delivery to the medial preoptic area and the rostral part of the PVN (see Results).

Coordinates for proper implant placement in the posterior BST were first piloted using the distribution of androgen receptors induced by $\mathrm{DHT}$ and $\mathrm{HF}$ in castrated male rats 2 weeks after stereotaxic surgery. As androgen receptor staining is abolished or restricted to the cytoplasm following removal of endogenous testosterone, we used the pattern and quality of staining to provide an index of transport and delivery. Coordinates used for proper placement in experimental animals were $0.15 \mathrm{~mm}$ caudal to bregma, $1.5 \mathrm{~mm}$ lateral to the midline, and $6 \mathrm{~mm}$ ventral from the pia. Drugs were dissolved in a heated suspension of beeswax (VWR International, Buffalo Grove, IL) to a final concentration of $0.3 \mathrm{M}$ (Christensen and Gorski, 1978; Lund 
et al, 2006), packed to a height of $400 \mu \mathrm{m}$, and ejected using a 28-gauge wire that extended $0.5 \mathrm{~mm}$ beyond the tip of the ejector cannula. This delivery method is able to induce androgen receptors for at least 2 weeks (see Williamson et al, 2010). Control animals received unilateral implants of beeswax alone. To avoid functional differences attributed to laterality, half of the animals received unilateral implants on either the left or right sides of the posterior BST.

\section{Blood Sampling and Hormone Assays}

At 2 weeks after stereotaxic surgery, plasma testosterone and corticosterone were measured under basal conditions and at $30 \mathrm{~min}$ of restraint to verify the concentration and stability of testosterone replacement, as well as to survey possible implant effects on HPA outflow. Blood samples were obtained via the tail vein immediately after removal from the home cage and/or at the termination of a single exposure to stress, which involved placing rats into flat bottom Plexiglas restrainers $\left(8.5 \times 21.5 \mathrm{~cm}^{2}\right.$; Kent Scientific, Litchfield, CT). The $30 \mathrm{~min}$ sampling time point is reliable for detecting central influences of androgens on HPA outflow and PVN Fos responses (Viau et al, 2003). Plasma testosterone $(25 \mu \mathrm{l})$ and corticosterone $(5 \mu \mathrm{l})$ concentrations were measured using commercial RIA kits and ${ }^{125}$ I-labeled ligands (MP Biomedical, Solon, $\mathrm{OH}$ ). The intra- and interassay coefficients of variation for both assays ranged from 3 to 6 and 10 to $12 \%$, respectively. The standard curve ED-50 for the testosterone RIA was $1.2 \mathrm{ng} / \mathrm{ml}$, with a detection limit of $0.1 \mathrm{ng} / \mathrm{ml}$. The standard curve ED-50 for the corticosterone RIA was $17 \mu \mathrm{g} / \mathrm{dl}$, with a detection limit of $0.625 \mu \mathrm{g} / \mathrm{dl}$.

\section{Perfusion and Tissue Processing}

Immediately after blood sampling, rats were perfused under deep chloral hydrate anesthesia $(350 \mathrm{mg} / \mathrm{kg}$, intraperitoneal), reliably achieved within 1-2 min of drug administration. Rats were perfused via the ascending aorta with ice-cold $0.9 \%$ saline and then $4 \%$ paraformaldehyde $(\mathrm{pH}$ 9.5). Brains were post-fixed for $4 \mathrm{~h}$ and stored overnight with $15 \%$ sucrose in $0.1 \mathrm{M}$ potassium PBS (KPBS, $\mathrm{pH} 7.3$ ) before slicing. Five 1 -in-5 series of frozen $30-\mu \mathrm{m}$-thick coronal sections were collected through the length of the brain and stored at $-20^{\circ} \mathrm{C}$ in cryoprotectant $(30 \%$ ethylene glycol and $20 \%$ glycerol). Adjacent tissue series from individual animals were used for separate immunocytochemical and in situ hybridization analyses.

\section{Immunohistochemistry}

Androgen receptor-immunoreactivity (-ir) was localized using a primary antiserum $(0.025 \mu \mathrm{g} / \mathrm{ml} ; 1: 8 \mathrm{k})$ raised against the androgen receptor (sc-816, Lot. number E1004; Santa Cruz Biotechnology, Santa Cruz, CA). Restraintresponsive neurons were localized employing Fos-ir as a marker of cellular activation using a primary antiserum (1:40k) raised against the human Fos protein (Ab-5, Lot. number 4191-1-1; Oncogene Research Products, Boston, MA). Conventional nickel-intensified, avidin-biotin-immunoperoxidase (Vectastain Elite ABC kit; Vector laboratories, Burlington, CA) procedures were used for both Fos and androgen receptor detection. Total cell number estimates of Fos-ir cells were generated by counting the number of positive cells per region, averaged for slice number, corrected for double counting errors (Guillery, 2002), and multiplying this product by a factor of five to account for slice frequency (one in five sections).

\section{Hybridization Histochemistry}

Described in greater detail elsewhere (Simmons et al, 1989; Williamson et al, 2010), an in situ hybridization approach was employed using ${ }^{33} \mathrm{P}$-UTP-labeled (GE Healthcare BioSciences, Baie d'Urfe, QC, Canada) antisense cRNA probes to determine relative levels of CRH and AVP mRNA in the PVN and in central and medial amygdala nuclei, respectively, and for the AVP transcript in the posterior BST. The $\mathrm{CRH}$ mRNA probe was transcribed from a full-length $(1.2 \mathrm{~kb}) \mathrm{cDNA}$ encoding the rat $C R H$ gene (Dr K Mayo, Northwestern University, Evanston, IL). The AVP mRNA probe was transcribed from a 230-bp fragment of the $3^{\prime}$ end of exon C encoding the rat vasopressin gene (Dr D Richter, University of Hamburg, Hamburg, Germany).

Of the two GABA-synthesizing enzymes, GAD enzyme 65 and $67 \mathrm{kDa}$ isoforms, a single episode of restraint causes a preferential and transient increase in GAD 67 mRNA levels. In contrast, repeated restraint causes a selective increase in basal GAD 65 mRNA levels (Bowers et al, 1998). Taken as markers of state-dependent and de novo changes in GABA synthesis, relative levels of GAD $65 \mathrm{mRNA}$ under basal conditions and GAD $67 \mathrm{mRNA}$ after $30 \mathrm{~min}$ of restraint, respectively, were assessed in the posterior BST using fulllength probes for mRNA encoding GAD 65 and GAD 67 (2.01 and $2.7 \mathrm{~kb}$, respectively; $\operatorname{Dr} \mathrm{A}$ Tobin, University of California, Los Angeles, Los Angeles, CA) (Erlander et al, 1991).

Parceling of the rat brain, as defined by the morphological features provided by thionin staining, was based on the terminology of Swanson (2004), and of Swanson and coworkers to describe the PVN (Swanson and Kuypers, 1980), posterior BST (Dong and Swanson, 2004), and central and lateral amygdala (Canteras et al, 1995; Dong et al, 2001), and of $\mathrm{Li}$ and Sawchenko (1998) to describe the lateral septum. Localization of transcripts and Fos-ir to different regions of the PVN was defined by redirected sampling of Nissl staining patterns aligned to adjacent corresponding dark- and bright-field images (Viau and Sawchenko, 2002). Light- and dark-level images were captured using a Retiga 1300 CCD digital camera (Q-imaging, Burnaby, BC, Canada), analyzed using Macintosh OS X-driven, Open Lab Image Improvision software (version 3.0.9, Quorum Technologies, Guelph, ON, Canada) and Image J software (version 1.38, NIH, Bethesda, MD).

\section{Statistics}

Group data from the hormone assays were compared using a two-way (between-treatment, within-subject) mixeddesign ANOVA using time as the repeated measure. As comparisons were made between control and implant sides of the brain, immunoperoxidase and hybridization analyses were compared using a two-way (between-treatment, within-subject) mixed-design ANOVA using side as the repeated 
measure. When main effects and interactions between treatment and side were found to be significant $(P<0.05)$, additional comparisons were made using Newman-Keuls post hoc test. Data were analyzed using the Aabel Gigawiz statistical software (version 3.0.4) using absolute measures in all cases. To underscore effects lateralized to the sides of the nuclei ipsilateral to the posterior BST implants, data are illustrated as the mean \pm SEM percentage of the contralateral (non-implanted) side. Comparisons were made observer-blind by assigning coded designations to data and tissue sets in advance.

\section{RESULTS}

\section{Implant Placements}

On the basis of the pattern of androgen receptor staining induced by DHT and HF in castrated male rats, the radius of drug transport was fairly consistent between animals and never exceeded greater than $400-500 \mu \mathrm{m}$ from the edge of the implants. Animals bearing proper implants of DHT showed induction of androgen receptor staining within each of the major nuclei of the posterior BST, confined to the ipsilateral side (Figure 1). The distribution and intensity of nuclear staining was comparable in animals bearing $\mathrm{HF}$ implants, suggesting similar transport and uptake (data not

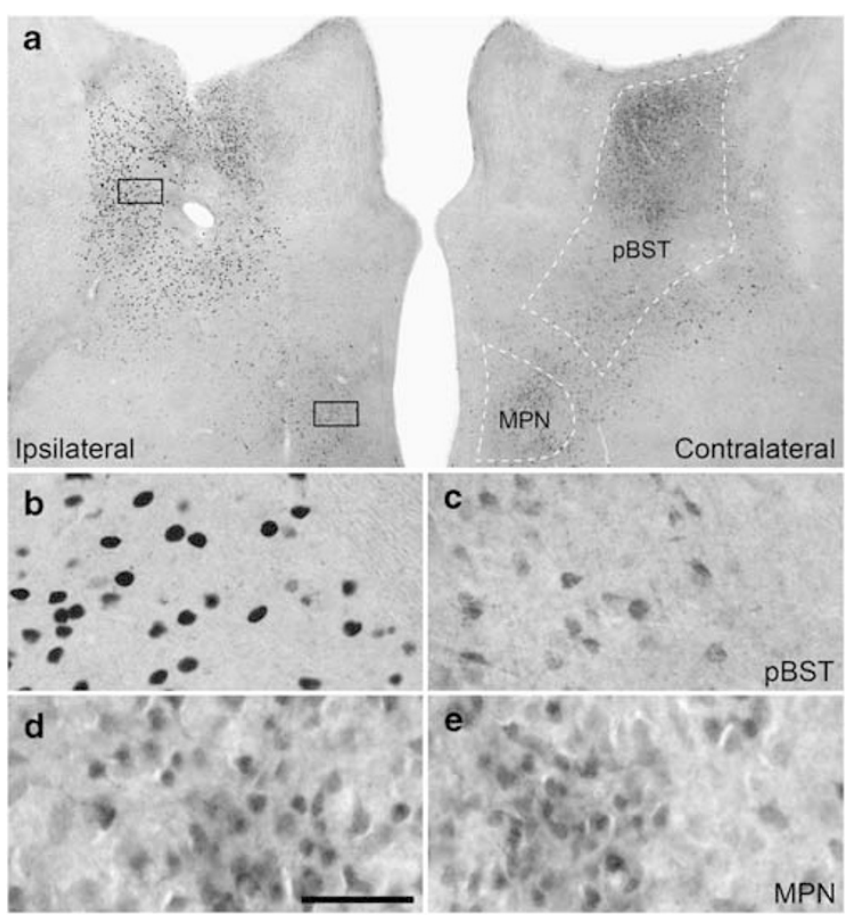

Figure I Representative bright-field photomicrographs to show the unilateral induction of androgen receptor (AR) staining after implants of dihydrotestosterone (DHT) in castrated male rats. Low magnification view (a) shows that $A R$ induction is restricted to the major nuclei of the posterior bed nuclei of the stria terminalis (BST), ipsilateral (left), but not contralateral (right) to the side of the DHT implant. Enlarged views of the boxed regions to show nuclear staining for AR within the ipsilateral (b), but not the contralateral BST (c), whereas AR staining is diffusely located within the cytoplasm of the adjacent (d) and contralateral (e) medial preoptic nucleus (MPN). Scale bar $=40 \mu \mathrm{m}$ for (b-e) and $400 \mu \mathrm{m}$ in (a). shown, see Williamson et al (2010)). Androgen receptor induction was not detectable within periventricular structures or within the adjacent medial preoptic nucleus, which normally contains a high concentration of androgen receptors and provides an inhibitory influence on HPA effector neurons of the PVN (Williamson and Viau, 2008). No lateralized effects were observed for androgen receptor staining within the PVN proper and surround, or within cells occupying the anterior division of the BST. Experimental animals showing implants that missed the intended centrolateral part of the posterior BST or placement to suggest ventricular contamination were removed from subsequent analyses. On the basis of these exclusion criteria, a final $n$ value of 5 was achieved for each of the BST implant groups.

Local DHT implants in the brain have been shown to modestly increase AVP expression within the posterior BST (Brot et al, 1993; de Vries et al, 1986). Thus, relative levels of AVP mRNA were assessed as a function of treatment status to confirm local drug delivery. There were no significant effects of treatment $(\mathrm{F}(3,16)=0.22 ; P>0.5)$ and side $(\mathrm{F}(1$, 16) $=0.56 ; P=0.47)$, but a significant interaction between treatment and side $(\mathrm{F}(3,16)=4.53 ; P=0.02)$. The basis for the interaction occurred in animals bearing DHT implants, who showed higher levels of the AVP transcript on the ipsilateral compared with the contralateral side of the posterior BST (Figure 2). This lateralized response did not occur in animals bearing a mixture of DHT and HF, indicating an androgen receptor requirement for the effect of DHT. Collectively, these findings provide a functional
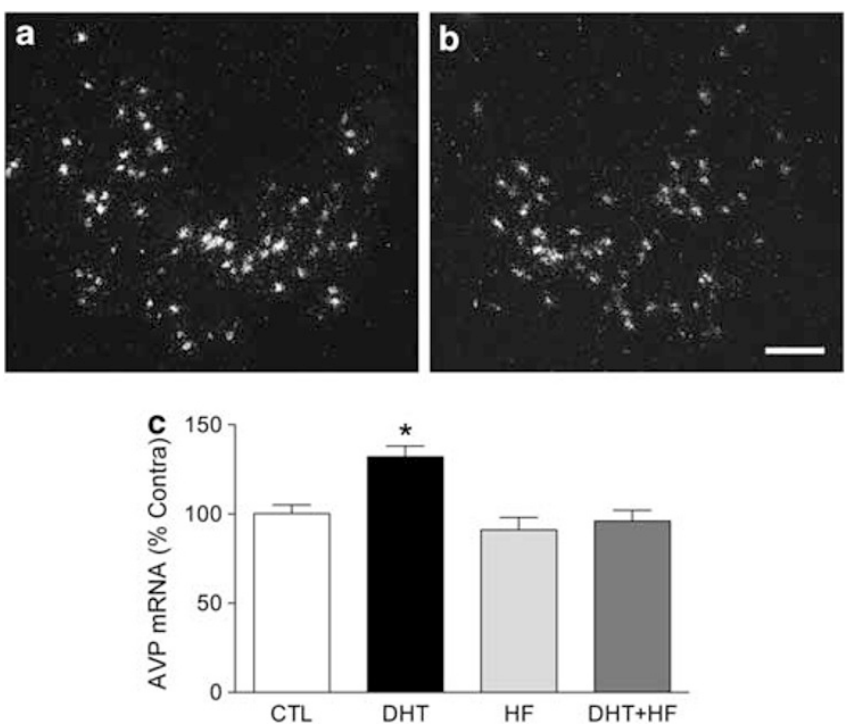

Figure 2 Representative dark-field photomicrographs to show arginine vasopressin (AVP) mRNA expression under basal conditions on the sides of the ventral region of the posterior bed nuclei of the stria terminalis (BST), ipsilateral (a) and contralateral (b) to the side of the dihydrotestosterone (DHT) implant. Note the relative increase in the hybridization signal for AVP displayed on the ipsilateral compared with the contralateral side. Scale bar $=150 \mu \mathrm{m}$. Mean \pm SEM relative optical density measures (\% of contralateral values, within treatment) of AVP mRNA (c) through the extent of the posterior BST (four serial sections) in animals bearing control (CTL), DHT, and hydroxyflutamide (HF) implants alone or in combination (dihydrotestosterone (DHT) + hydroxyflutamide $(\mathrm{HF})$ ). ${ }^{*} P<0.05$ vs the contralateral side ( $n=5$ per group). 
indication that the posterior BST was effectively targeted in the experimental animals chosen for analysis.

Critically, as with all of the parameters of interest in this study (see Results), there was no lateralized effect for AVP expression in control animals bearing unilateral implants of beeswax to suggest the possibility of space-occupying lesions. For any effect observed, we found no differences between implants placed on the left compared with the right side of the posterior BST.

\section{Plasma Hormone Levels}

For testosterone, there were no significant effects of treatment $(\mathrm{F}(3,16)=0.31 ; P>0.5)$ and stress $(\mathrm{F}(1$, $16)=1.53 ; P=0.23)$, and no significant interaction between treatment and stress $(\mathrm{F}(3,16)=1.34 ; P=0.29)$. Collapsing across the 0 and 30 min time points, mean \pm SEM plasma testosterone concentrations were: control, $0.49 \pm 0.03 \mathrm{ng} / \mathrm{ml}$; DHT, $0.47 \pm 0.02 \mathrm{ng} / \mathrm{ml} ; \mathrm{HF}, 0.46 \pm 0.4 \mathrm{ng} / \mathrm{ml})$, and DHT + $\mathrm{HF}, 0.51 \pm 0.04 \mathrm{ng} / \mathrm{ml}$. On the basis of a previous report employing testosterone capsules similar to our own (Singh
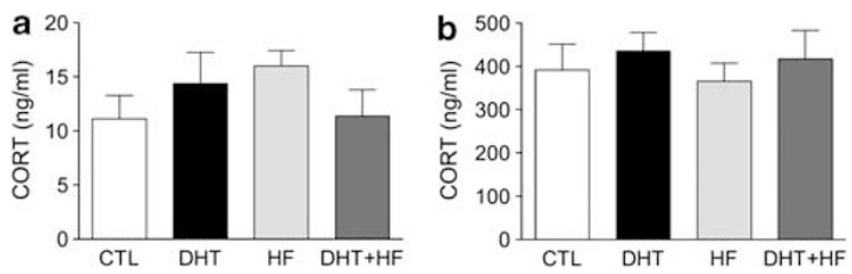

Figure 3 Mean \pm SEM plasma corticosterone (CORT) concentrations at 0 min (a) and at $30 \mathrm{~min}$ (b) after the onset of a single episode of $30 \mathrm{~min}$ restraint stress in animals bearing unilateral implants of dihydrotestosterone (DHT), hydroxyflutamide (HF), or a mixture of both (DHT + HF) in the posterior bed nuclei of the stria terminalis (BST) ( $n=5$ per group). et al, 2000), we would estimate plasma DHT concentrations in the order of $0.02 \mathrm{ng} / \mathrm{ml}$. Thus, our replacement strategy provided background androgen levels that were stable and sufficiently low enough across treatment groups to credit drug effects primarily to local changes in androgen receptor occupancy in the posterior BST.

As illustrated in Figure 3, plasma corticosterone concentrations were reliably increased by restraint exposure $(\mathrm{F}(1,16)=252.12 ; P<0.0001)$. As expected, there was no significant effect of treatment $(\mathrm{F}(3,16)=0.25 ; P>0.5)$ and no significant interaction between treatment and time $(\mathrm{F}(3$, $16)=0.36 ; P>0.5)$ to suggest an influence of the unilateral implants to modulate HPA outflow. It is also worth noting that corticosterone and testosterone in circulation can interact on PVN motor neuron drive (Viau et al, 1999). Taken together, the hormone data validate our combined BST and peripheral implant approach, as it allows us to study the effects of androgen receptors in the posterior BST in isolation of other potential sources of androgen- and glucocorticoid-sensitive input to the PVN.

\section{Implant Effects on Neuropeptide Expression}

$C R H$ and AVP mRNA in the PVN. Densitometric analysis of the relative levels of $\mathrm{CRH}$ mRNA in the hypophysiotropic, dorsal medial parvicellular (mpd) compartment of the PVN (Figure 4, bottom panels) revealed no significant effects of treatment $(\mathrm{F}(3,16)=1.92 ; P=0.17)$ and side $(\mathrm{F}(1$, $16)=0.04 ; P>0.5)$, and no significant interaction between treatment and side $(\mathrm{F}(3,16)=2.22 ; P=0.13)$ under basal conditions. With respect to AVP (Figure 3, top panels), materials from the same experiment revealed no significant effect of treatment $(\mathrm{F}(3,16)=2.01 ; P=0.16)$. However, there was a significant effect of side $(F(1,16)=23.25$; $P=0.0002)$ and a significant interaction between treatment
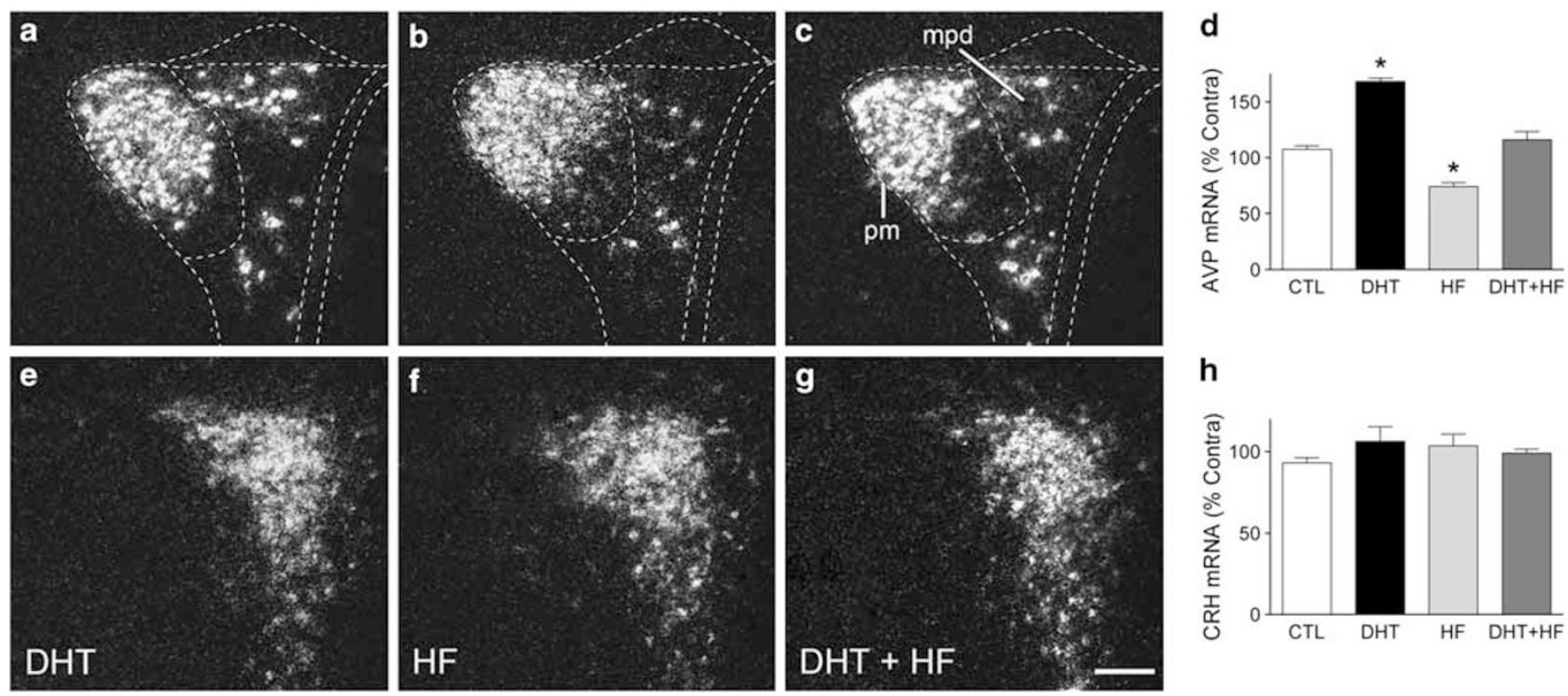

Figure 4 Representative dark-field photomicrographs to show the spatial pattern of arginine vasopressin (AVP) (a-c) and corticotrophin-releasing hormone $(\mathrm{CRH})(\mathrm{e}-\mathrm{g}) \mathrm{mRNA}$ expression under basal conditions in the medial dorsal parvocellular $(\mathrm{mpd})$ and posterior magnocellular (pm) parts of the ipsilateral paraventricular nucleus (PVN) in animals bearing unilateral implants of dihydrotestosterone (DHT), hydroxyflutamide (HF), or a mixture of both $(\mathrm{DHT}+\mathrm{HF})$ in the posterior bed nuclei of the stria terminalis (BST). Scale bar $=100 \mu \mathrm{m}$. Mean \pm SEM relative optical density measures (\% of contralateral values, within treatment) of AVP (d) and $\mathrm{CRH}(\mathrm{h})$ mRNA expression within the mpd region of the PVN in animals bearing control (CTL) wax, and DHT and $H F$ implants either alone or in combination (DHT + HF). $* P<0.05$ vs the contralateral side ( $n=5$ per group). 
and side $(F(3,16)=36.74 ; P<0.0001)$. The basis for the effect of side and the interaction occurred as a consequence of relatively higher levels of AVP mRNA within the DHT group and relatively lower levels of AVP mRNA within the HF group, on the sides of the PVN ipsilateral to the BST implants (Figure 4, top panels). There was no lateralized effect in animals receiving DHT and HF combined, confirming a role for the androgen receptor to mediate the stimulatory influence of DHT.

CRH and AVP mRNA in the amygdala. CRH and AVP mRNA in the central and medial nuclei of the amygdala, respectively, increase in response to elevations of testosterone in circulation (Viau et al, 2001). As both of these regions are densely innervated by the posterior BST, the relative levels of these transcripts were surveyed as a function of treatment status under basal conditions. For the $\mathrm{CRH}$ transcript in the central nucleus, there were no significant effects of treatment $(\mathrm{F}(3,16)=1.01 ; P=0.41)$ and side $(\mathrm{F}(1,16)=2.42 ; P=0.14)$, and no significant interaction between treatment and side $(\mathrm{F}(3,16)=1.24$; $P=0.19)$. For the AVP transcript in the medial nucleus, there were no significant effects of treatment $(\mathrm{F}(3$, 16) $=0.26 ; P>0.5)$ and side $(\mathrm{F}(1,16)=0.39 ; P>0.5)$, and no significant interaction between treatment and side $(\mathrm{F}(3$, $16)=0.34 ; P>0.5)$. The negative findings for $\mathrm{CRH}$ may be explained by the prominence of posterior BST projections to the medial, but not the lateral $\mathrm{CRH}$-expressing part of the central amygdalar nucleus (Honkaniemi et al, 1992). The lack of effect on AVP provides reassurance that the medial preoptic nucleus was effectively avoided by the BST implants, as testosterone implants in the vicinity of the medial preoptic nucleus stimulate AVP mRNA levels in the medial amygdala (Williamson et al, 2010).

\section{Implant Effects on Activational Responses to Acute Restraint Stress}

$M p d$ region of the PVN. Control animals expressed few, if any, Fos-ir neurons in the PVN under basal conditions. No main effects or interactions were revealed for any of its major divisions. Restraint-induced Fos-ir was concentrated within the PVN mpd region (Figure 5), with few to scattered labeling within the autonomic-related subdivisions and in the posterior magnocellular division of the PVN. For the mpd region, there were no significant effects of treatment $(\mathrm{F}(3,16)=2.32 ; \quad P=0.11)$ and side $(\mathrm{F}(1,16)=2.90$; $P=0.11)$, but a significant interaction between treatment and side $(\mathrm{F}(3,16)=4.99 ; P=0.012)$. The basis for this interaction occurred as a consequence of relatively higher numbers of Fos-positive cells in the DHT group and lower numbers in the HF group, focused on the sides of the PVN ipsilateral to the BST implants (Figure 5). No lateralized effects occurred for stress-induced Fos in animals bearing a mixture of DHT and HF implants in the posterior BST.

Lateral septum and medial amygdala. The posterior BST issues prominent projections to the lateral septum and medial amygdala (Dong and Swanson, 2004; Gu et al, 2003). Each of these, in turn, is capable of regulating PVN motor neurons (Herman et al, 2003). Therefore, we extended our survey to these regions using the same material used for the PVN under basal and stress conditions. For both the lateral septal and medial amygdala nuclei in unstressed animals, there were no effects of treatment and side, and no interactions between treatment and side $(P>0.5$ in all cases).

In animals exposed to restraint, there were no significant effects of treatment $(\mathrm{F}(3,16)=1.51 ; P=0.25)$ and side $(\mathrm{F}(1$, 16) $=1.97 ; P=0.18$ ), and no significant interaction between treatment and side $(\mathrm{F}(3,16)=0.90 ; P=0.46)$ to suggest that androgen receptors in the posterior BST influence Fos responses within the lateral septal nucleus. For the medial amygdala, Fos induction was most prominent within the posterodorsal part, with fewer cells detected in the posteroventral and anteroventral parts of the nucleus (Figure 6). Focused within the posterodorsal part of the medial amygdala, there was no significant effect of treatment $(\mathrm{F}(3,16)=0.29 ; P>0.5)$, but a significant effect of side $(\mathrm{F}(1$, $16)=13.78 ; \quad P=0.0019)$ and a significant interaction between treatment and side $(\mathrm{F}(3,16)=9.33 ; P=0.008)$. The basis for the effect of side and the interaction occurred as a consequence of higher number of Fos-positive cells in the DHT group, on the sides of the medial amygdala ipsilateral to the BST implants (Figure 6). There were no lateralized effects for Fos-ir in animals bearing HF alone or DHT and HF implants combined.
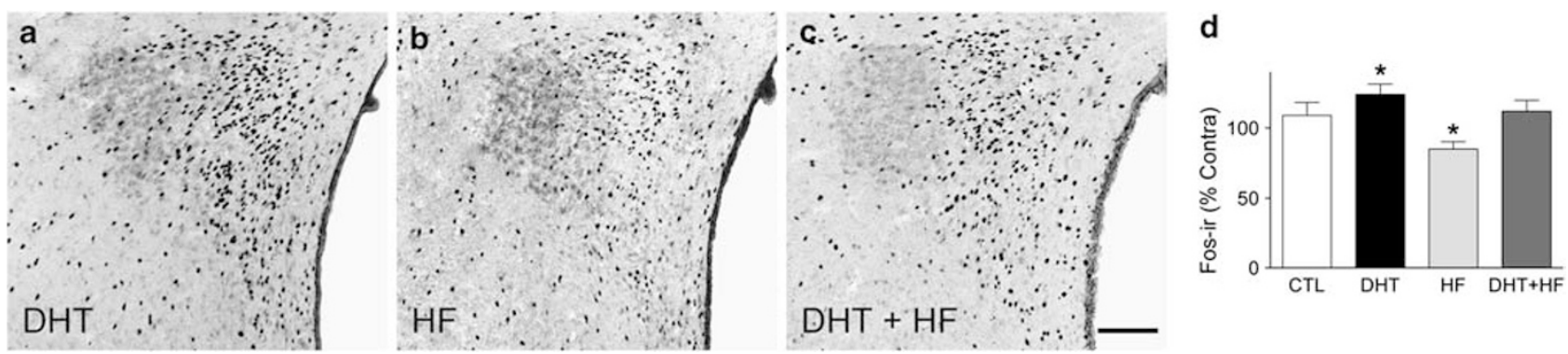

Figure 5 Representative bright-field photomicrographs to show Fos-immunoreactivity (ir) staining at 30 min of restraint exposure focused within medial parvocellular neurons on the ipsilateral sides of the paraventricular nucleus (PVN) in animals bearing unilateral implants of dihydrotestosterone (DHT), hydroxyflutamide (HF), or a mixture of both (DHT + HF) in the posterior bed nuclei of the stria terminalis (BST) (a-c, respectively). Note the relative decrement in Fos staining in HF-implanted animals compared with those receiving DHT or DHT and HF combined. Scale bar $=100 \mu \mathrm{m}(\mathrm{a}-\mathrm{c})$. Mean $\pm \mathrm{SEM}$ relative numbers (percentage of contralateral values, within treatment) of medial parvocellular Fos-ir neurons (d) in animals bearing control (CTL), and DHT and HF implants either alone or in combination (DHT + HF). $* P<0.05$ vs the contralateral side ( $n=5$ per group). 

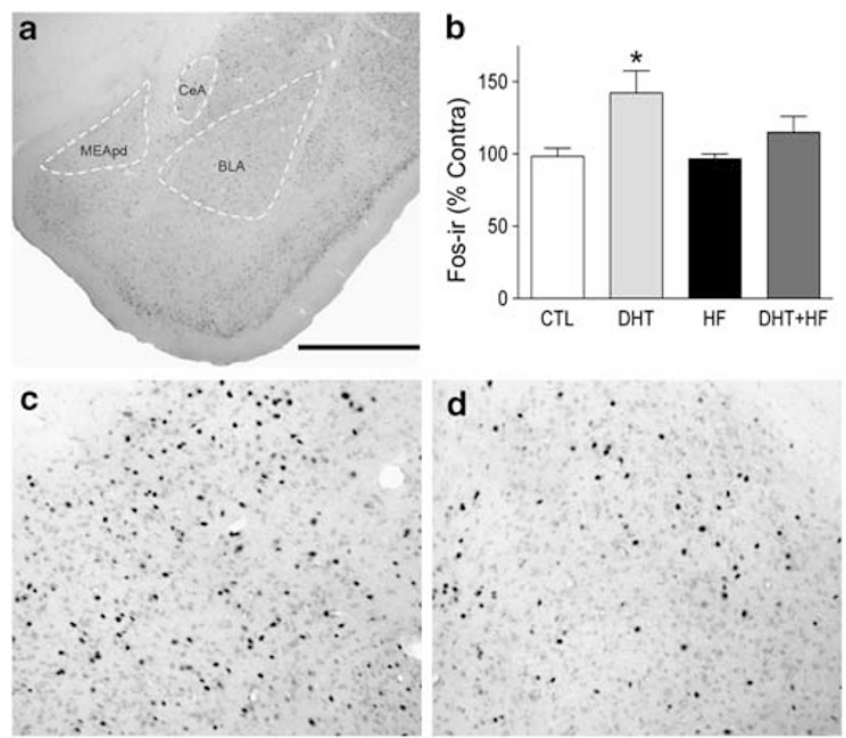

Figure 6 Representative bright-field photomicrographs (a) to show Fosimmunoreactivity (ir) staining at 30 min of restraint exposure within central (CeA), basolateral (BLA), and medial amygdala nuclei (posterodorsal part, MEApd) of a control, wax-implanted animal. Relative to the remainder of the amygdala, the number of cells recruited to express Fos protein was most reliable within the MeApd. Mean \pm SEM relative numbers (percentage of contralateral values, within treatment) of Fos-ir neurons (b) through the extent of the MEApd (three serial sections) in animals bearing control $(\mathrm{CTL})$, and dihydrotestosterone (DHT) and hydroxyflutamide (HF) implants either alone or in combination (DHT + HF). ${ }^{*} P<0.05$ vs the contralateral side $(n=5)$. High magnification views of the MEApd region to show Fos-ir at 30 min of restraint on the sides of the MEApd ipsilateral (c) and contralateral (d) to the side of the DHT implant. Note the relative increase in Fos staining on the ipsilateral side. Scale bar $=1000 \mu \mathrm{m}$ in (a) and $125 \mu \mathrm{m}$ for $(\mathrm{c}-\mathrm{d})$.

\section{GAD 65 and GAD 67 mRNA Expression in the Posterior BST}

Stressed induced changes in GABA neurotransmission within PVN-projecting populations have been proposed to provide a mechanism for regulating PVN and HPA axis responses (Herman et al, 2005). GAD expression and activity within several brain regions is altered by testosterone in circulation (Searles et al, 2000), as well as by restraint stress (Bowers et al, 1998). Prompted by the strength to which the PVN responded to the DHT implants, we anticipated a local influence for androgen receptors to regulate GAD mRNA expression in the posterior BST. For the GAD 65 isoform in unstressed animals, there were no significant effects of treatment $(\mathrm{F}(3,16)=0.45 ; P>0.5)$ and side $(\mathrm{F}(1,16)=3.0 ; P=0.18)$, and no significant interaction between treatment and side $(\mathrm{F}(3,16)=0.038 ; P>0.5)$. For the GAD 67 isoform in animals exposed to restraint, there were no significant effects of treatment $(\mathrm{F}(3,16)=2.56$; $P=0.19)$ and side $(\mathrm{F}(1,16)=2.34 ; P=0.14)$, and no significant interaction between treatment and side $(\mathrm{F}(3$, 16) $=0.26 ; P>0.5)$. Collectively, these results suggest that the stimulatory effects of DHT on PVN responses are not predicted by local preemptive or stress-induced changes in GABA synthesis in the posterior BST.

\section{DISCUSSION}

Lesion studies indicate that the posterior BST inhibits HPA axis responses to stress and PVN-projecting neurons in this region contain a high density of androgen receptors. We anticipated, therefore, a role for androgen receptors within the posterior BST to inhibit central indices of HPA function. We exploited the unilateral projection profile of the posterior BST by introducing unilateral implants of the androgen DHT, or the androgen receptor blocker HF into the posterior BST region. The posterior BST contains estrogen receptors (Shughrue et al, 1997; Simerly et al, 1990) and has the capacity to convert testosterone and its metabolites to estrogen (Lund et al, 2006; Zhao et al, 2007). Therefore, to determine the sex steroid hormone receptor basis for the effects of DHT, our study also included an additional group of animals receiving an admixture of DHT and HF.

We initially considered removing all sources of androgens by employing castrated animals for our studies. Androgen receptors are contained within a massive array of cell groups identified as projecting to the PVN, as well as to the posterior BST. Moreover, testosterone and its metabolites have been shown to exert local effects in the vicinity of the PVN in addition to the medial preoptic nucleus, which also communicates with the PVN and the posterior BST. Finally, castration stimulates all levels of the HPA axis, as well as neuropeptide expression within multiple afferent regulators of the PVN (Viau et al, 2003). Rather than testing the influence of the posterior BST to counteract or compete with a global stimulatory influence of castration on the PVN and its extended circuitries, we chose instead to use castrated animals replaced with low physiological levels of testosterone. By supplying the remainder of the brain with low background levels of testosterone, this allowed us to credit drug effects primarily to local changes in androgen receptor signaling in the posterior BST.

In line with the unilateral projections of the posterior BST, the basic effects of the implants were lateralized to the sides of the PVN ipsilateral to the posterior BST implants. In unstressed animals, DHT and HF implants exerted stimulatory and inhibitory effects, respectively, on AVP mRNA within in the PVN mpd region. However, there was no effect of drug treatment on CRH expression in the PVN. As with our previous transcriptional, median eminence content, and immunohistochemical studies (reviewed by Williamson et al (2005), and see Williamson and Viau (2008)), the current results continue to suggest that androgens act in the brain to selectively target the capacity of PVN neurons to synthesize AVP.

Opposite to our expectations, stress-induced Fos protein responses in the PVN were increased in response to DHT and decreased in response to HF implants. Moreover, the opposing influences of these drugs were restricted to the mpd HPA-regulating zone of the PVN. No such lateralized effects were observed in animals receiving a mixture of DHT and HF, confirming an androgen receptor mode of action for DHT.

The posterior division of the BST has three major nuclei: principal, interfascicular, and transverse, all of which contain androgen receptors (see Figure 7). However, it is the principle nucleus that preferentially innervates the 


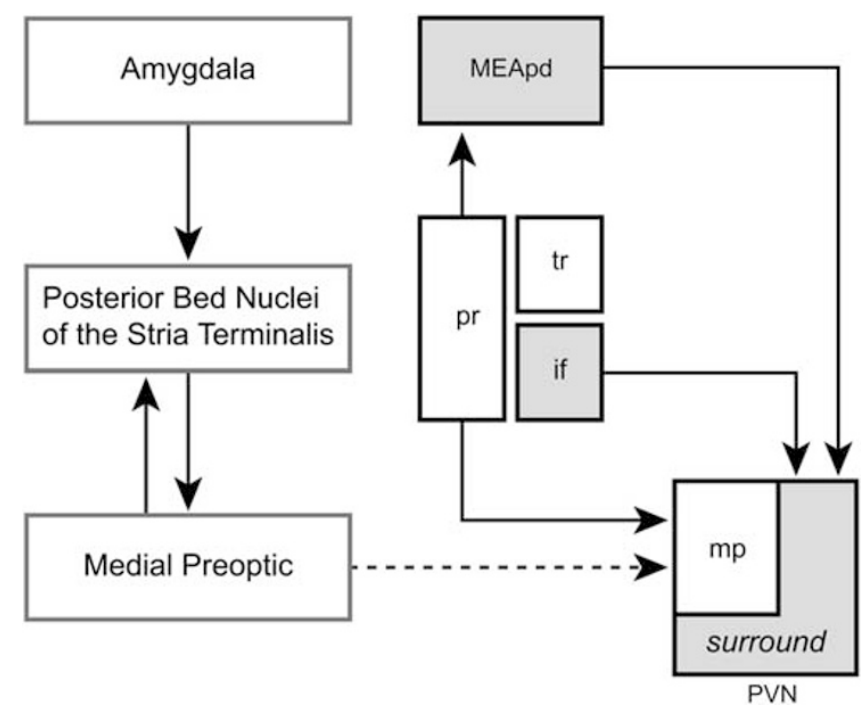

Figure 7 Based on previous connectivity studies and our current findings, this schematic illustrates candidate circuits mediating the stimulatory effects of dihydrotestosterone (DHT) in the posterior bed nuclei of the stria terminalis (BST) on the paraventricular nucleus (PVN) of the hypothalamus. These results support a direct pathway from the principle (pr) nucleus of the posterior BST to the neuroendocrine (medial parvocellular) part of the PVN. The posterodorsal part of the medial amygdala (MEApd) and interfascicular (if) nucleus of the posterior BST do not innervate the neuroendocrine part of the PVN, but innervate the area surrounding the PVN (shaded regions). Both of these components may be in a position to regulate input from other limbic regions, albeit indirectly. In contrast to our current findings, androgen receptors in medial preoptic nuclei inhibit the PVN (dashed line). Thus, the central effects of androgens on hypothalamic-pituitary-adrenal (HPA) axis responses to stress may reflect the net of stimulatory and inhibitory influences on PVN motor neuron drive.

medial parvicellular HPA-regulating zone of the PVN $(\mathrm{Gu}$ et al, 2003). The transverse nucleus innervates, at best, the anterior parvicellular part of the PVN (Dong and Swanson, 2004). The interfascicular nucleus innervates regions immediately adjacent to the PVN proper (Dong and Swanson, 2004), and is in a position to influence limbic inputs to the HPA axis, albeit indirectly. Thus, AVP mRNA and cellular activation of the PVN may depend on androgen receptors in both the principle and interfascicular nuclei, although the precise origin of this influence still remains unknown (Williamson and Viau, 2007).

Separate populations in the posterior BST project back to a variety of limbic-forebrain regions implicated in HPA axis control, including the lateral septal and adjacent medial amygdala nuclei (Dong and Swanson, 2004). Both of these regions project extensively to $\mathrm{BST}$ and/or hypothalamic neurons relaying information to the PVN proper and surround, and are in a position to modulate PVN and HPA responses to restraint stress (Herman et al, 2003, 2005). There were no lateralized effects for stress-induced Fos in the lateral septum to suggest a dependency on androgen receptors in the posterior BST. However, DHT caused a HF-reversible increase in the number of cells recruited to express Fos protein on the side of the medial amygdala ipsilateral to the side of the BST implants. We have yet to map the containment of androgen receptors within posterior BST identified as projecting to the medial amygdala. Nonetheless, our data suggest that the increase in cellular activation in the medial amygdala in response to DHT is predictive of driving PVN responses to stress and dependent on androgen receptors in the posterior BST.

The results support a role for androgen receptors in the posterior BST to provide a stimulatory influence on the PVN, as well as its extended circuitries. However, this still leaves open the question as to why targeted lesions of the posterior BST suggest an involvement for this region in HPA axis inhibition (Choi et al, 2007). Also in contrast to these results, we had previously observed an inverse relationship between the number of androgen receptors in the posterior BST and the magnitude of the HPA axis response to stress (Bingham and Viau, 2008). Towards explaining these dissenting findings, as previously raised by Dong and Swanson (2004), any one of the major cell groups of the posterior BST could have distinctive capacities for responding to local changes in androgen exposure. In other words, our findings may speak to a smaller subset of androgen-sensitive neurons in the posterior BST that are uniquely responsible for regulating the PVN. If diminutive in size relative to the remaining number of PVN afferents, this could also reconcile the predominately stimulatory effect of posterior BST lesions on PVN and HPA stress axis responses.

As a final consideration, testosterone in circulation would naturally be expected to impact the posterior BST bilaterally. Thus, our unexpected results may be unique to the unilateral conditions imposed. Therefore, whether bilateral implants of DHT into the BST might continue to reflect stimulatory effects on PVN motor neuron function is worthy of pursuit, in addition to HPA output. Nonetheless, given the inherent difficulties in attributing changes in HPA outflow to central interactions between androgens and corticosteroids, our current approach provides a critical first step in understanding how androgen receptors in the BST operate on the PVN independent of secondary physiological responses.

PVN neurons are richly innervated by GABAergic cell populations from the posterior BST (Polston et al, 2004). Further, GABA synthesis and turnover in the brain is remarkably sensitive to alterations in circulating testosterone concentrations (Grattan and Selmanoff, 1993). Thus, we anticipated a local influence for androgen receptors to regulate GAD expression in the posterior BST. However, there were no lateralized effects on GAD 65 and GAD 67 mRNA levels to suggest a mechanism of GABA disinhibition, as previously proposed for other sources of GABAergic influences on the PVN (Herman et al, 2005). In agreement with the these negative results, GAD expression and activity in the posterior BST appear to be under the control of descending limbic inputs to this region (Mueller et al, 2006), as well as by estrogen metabolites of testosterone (Earley and Leonard, 1978).

The posterior BST hosts a variety of neurotransmitters and neuropeptides, including AVP (de Vries et al, 1984), CCK (Micevych et al, 1988), substance P (Malsbury and McKay, 1987), galanin (Planas et al, 1995), enkephalin, and glutamate (Poulin et al, 2009). The expression of several of these phenotypes is altered by sex hormones in both male and female rats (de Vries and Miller, 1998; Simerly et al, 1989). Any one of these may represent a candidate mediator for the effects of androgens on PVN responses. However, the connectivity of these neurotransmitters and neuropeptides in 
reference to PVN projecting neurons and identity with respect to androgen receptors has not been fully explored. On the basis of previous anatomical and functional evidence, the posterior BST has been interpreted to be involved in the control of reproductive and social behavior (see Dong and Swanson, 2004). In light of our current findings, the posterior BST may very well represent an important locus for registering situation-specific changes in gonadal status and distributing this information to both the reproductive and adrenal axes.

We are not about to conclude that the posterior BST registers changes in circulating testosterone solely to provide a stimulatory influence on PVN motor neuron responses. Rather, we propose that the net effect of testosterone to regulate PVN motor responses is determined by the relative contributions of different projection neurons in the posterior BST and their capacities for expressing estrogen and androgen receptors (see Dong and Swanson (2004)). Estrogen and testosterone in circulation cause opposing stimulatory and inhibitory influences, respectively, on the HPA axis (Lund et al, 2004; Viau and Meaney, 1991). Therefore, it would be helpful to determine whether the major nuclei of the posterior BST possess different propensities for metabolizing testosterone to estrogens and other androgenic forms.

In this same context, and in contrast to our current findings, androgens have been shown to act at the level of the medial preoptic nucleus and within the vicinity of the PVN region to inhibit stress PVN and HPA activity (Lund et al, 2006). As the magnitude of the HPA axis response to stress has been postulated to reflect the net influence of stimulatory and inhibitory drive to the $\mathrm{PVN}$, androgen receptor signaling in the posterior BST could contribute to the positive arm of this regulation. This may be of particular importance to conditions of chronic stress, where energetic demands are greater and a full HPA response is necessary for survival (Gomez and Dallman, 2001; Gray et al, 2010). Under these conditions, we propose that the posterior BST might be engaged to temper the inhibitory effect of circulating testosterone on HPA output. Thus, the extent to which the posterior BST is recruited to register and translate the effects of testosterone to the HPA axis may ultimately depend on the type, intensity, and duration of stress exposure. All of these variables contribute to stress pathology, including affective and physiological disorders.

We are only beginning to understand how the posterior BST mediates the distal effects of androgens on the PVN. The current results suggest that the posterior BST is not just a recipient of descending limbic influences, but also an important neural substrate capable of reciprocating androgen-sensitive information to upstream modulators of the HPA axis. Our unanticipated findings highlight the need for further systematic evaluation of central sex steroid hormone influences on the HPA axis. Studies of this nature will continue to provide a critical framework for understanding the basis for individual differences in stress resilience and predisposition to disease.

\section{ACKNOWLEDGEMENTS}

This study was supported by the Canadian Institutes of Health Research and the Natural Sciences and Engineering
Research Council of Canada (VV), Canadian Graduate Student Scholarships Doctoral Award from the Canadian Institutes of Health Research (BB), and Michael Smith Foundation for Health Research Senior Scholarship (VV) and Trainee Award (BB).

\section{DISCLOSURE}

The authors declare no conflict of interest.

\section{REFERENCES}

Bingham B, Viau V (2008). Neonatal gonadectomy and adult testosterone replacement suggest an involvement of limbic arginine vasopressin and androgen receptors in the organization of the HPA axis. Endocrinology 149: 3581-3591.

Bingham B, Williamson M, Viau V (2006). Androgen and estrogen receptor-beta distribution within spinal-projecting and neurosecretory neurons in the paraventricular nucleus of the male rat. J Comp Neurol 499: 911-923.

Bowers G, Cullinan WE, Herman JP (1998). Region-specific regulation of glutamic acid decarboxylase (GAD) mRNA expression in central stress circuits. J Neurosci 18: 5938-5947.

Brot MD, De Vries GJ, Dorsa DM (1993). Local implants of testosterone metabolites regulate vasopressin mRNA in sexually dimorphic nuclei of the rat brain. Peptides 14: 933-940.

Canteras NS, Simerly RB, Swanson LW (1995). Organization of projections from the medial nucleus of the amygdala: a PHAL study in the rat. J Comp Neurol 360: 213-245.

Choi DC, Furay AR, Evanson NK, Ostrander MM, Ulrich-Lai YM, Herman JP (2007). Bed nucleus of the stria terminalis subregions differentially regulate hypothalamic-pituitary-adrenal axis activity: implications for the integration of limbic inputs. J Neurosci 27: 2025-2034.

Christensen LW, Gorski RA (1978). Independent masculinization of neuroendocrine systems by intracerebral implants of testosterone or estradiol in the neonatal female rat. Brain Res 146: $325-340$.

Cullinan WE, Herman JP, Watson SJ (1993). Ventral subicular interaction with the hypothalamic paraventricular nucleus: evidence for a relay in the bed nucleus of the stria terminalis. J Comp Neurol 332: 1-20.

de Vries GJ (2008). Sex differences in vasopressin and oxytocin innervation of the brain. Prog Brain Res 170: 17-27.

de Vries GJ, Buijs RM, Sluiter AA (1984). Gonadal hormone actions on the morphology of the vasopressinergic innervation of the adult rat brain. Brain Res 298: 141-145.

de Vries GJ, Duetz W, Buijs RM, van Heerikhuize J, Vreeburg JT (1986). Effects of androgens and estrogens on the vasopressin and oxytocin innervation of the adult rat brain. Brain Res 399: 296-302.

de Vries GJ, Miller MA (1998). Anatomy and function of extrahypothalamic vasopressin systems in the brain. Prog Brain Res 119: 3-20.

Dong HW, Petrovich GD, Swanson LW (2001). Topography of projections from amygdala to bed nuclei of the stria terminalis. Brain Res Brain Res Rev 38: 192-246.

Dong HW, Swanson LW (2004). Projections from bed nuclei of the stria terminalis, posterior division: implications for cerebral hemisphere regulation of defensive and reproductive behaviors. J Comp Neurol 471: 396-433.

Earley CJ, Leonard BE (1978). GABA and gonadal hormones. Brain Res 155: 27-34.

Erlander MG, Tillakaratne NJ, Feldblum S, Patel N, Tobin AJ (1991). Two genes encode distinct glutamate decarboxylases. Neuron 7: 91-100. 
Gomez F, Dallman MF (2001). Manipulation of androgens causes different energetic responses to cold in 60- and 40-day-old male rats. Am J Physiol Regul Integr Comp Physiol 280: R262-R273.

Gomez F, Manalo S, Dallman MF (2004). Androgen-sensitive changes in regulation of restraint-induced adrenocorticotropin secretion between early and late puberty in male rats. Endocrinology 145: 59-70.

Grattan DR, Selmanoff M (1993). Regional variation in gammaaminobutyric acid turnover: effect of castration on gammaaminobutyric acid turnover in microdissected brain regions of the male rat. J Neurochem 60: 2254-2264.

Gray M, Bingham B, Viau V (2010). A comparison of two repeated restraint stress paradigms on hypothalamic-pituitary-adrenal axis habituation, gonadal status and central neuropeptide expression in adult male rats. J Neuroendocrinol 22: 92-101.

Gu G, Cornea A, Simerly RB (2003). Sexual differentiation of projections from the principal nucleus of the bed nuclei of the stria terminalis. J Comp Neurol 460: 542-562.

Guillamon A, Segovia S, del Abril A (1988). Early effects of gonadal steroids on the neuron number in the medial posterior region and the lateral division of the bed nucleus of the stria terminalis in the rat. Brain Res Dev Brain Res 44: 281-290.

Guillery RW (2002). On counting and counting errors. J Comp Neurol 447: 1-7.

Handa RJ, Nunley KM, Lorens SA, Louie JP, McGivern RF, Bollnow MR (1994). Androgen regulation of adrenocorticotropin and corticosterone secretion in the male rat following novelty and foot shock stressors. Physiol Behav 55: 117-124.

Herman JP, Figueiredo H, Mueller NK, Ulrich-Lai Y, Ostrander MM, Choi DC et al (2003). Central mechanisms of stress integration: hierarchical circuitry controlling hypothalamo-pituitary-adrenocortical responsiveness. Front Neuroendocrinol 24: 151-180.

Herman JP, Ostrander MM, Mueller NK, Figueiredo H (2005). Limbic system mechanisms of stress regulation: hypothalamopituitary-adrenocortical axis. Prog Neuropsychopharmacol Biol Psychiatry 29: 1201-1213.

Honkaniemi J, Pelto-Huikko M, Rechardt L, Isola J, Lammi A, Fuxe $\mathrm{K}$ et al (1992). Colocalization of peptide and glucocorticoid receptor immunoreactivities in rat central amygdaloid nucleus. Neuroendocrinology 55: 451-459.

Li HY, Sawchenko PE (1998). Hypothalamic effector neurons and extended circuitries activated in 'neurogenic' stress: a comparison of footshock effects exerted acutely, chronically, and in animals with controlled glucocorticoid levels. J Comp Neurol 393: $244-266$.

Lund TD, Hinds LR, Handa RJ (2006). The androgen 5alphadihydrotestosterone and its metabolite 5alpha-androstan-3beta, 17beta-diol inhibit the hypothalamo-pituitary-adrenal response to stress by acting through estrogen receptor beta-expressing neurons in the hypothalamus. J Neurosci 26: 1448-1456.

Lund TD, Munson DJ, Haldy ME, Handa RJ (2004). Androgen inhibits, while oestrogen enhances, restraint-induced activation of neuropeptide neurones in the paraventricular nucleus of the hypothalamus. J Neuroendocrinol 16: 272-278.

Malsbury CW, McKay K (1987). A sex difference in the pattern of substance P-like immunoreactivity in the bed nucleus of the stria terminalis. Brain Res 420: 365-370.

Micevych PE, Matt DW, Go VL (1988). Concentrations of cholecystokinin, substance $\mathrm{P}$, and bombesin in discrete regions of male and female rat brain: sex differences and estrogen effects. Exp Neurol 100: 416-425.

Mueller NK, Dolgas CM, Herman JP (2006). Regulation of forebrain GABAergic stress circuits following lesion of the ventral subiculum. Brain Res 1116: 132-142.

Planas B, Kolb PE, Raskind MA, Miller MA (1995). Sex difference in coexpression by galanin neurons accounts for sexual dimorphism of vasopressin in the bed nucleus of the stria terminalis. Endocrinology 136: 727-733.
Polston EK, Gu G, Simerly RB (2004). Neurons in the principal nucleus of the bed nuclei of the stria terminalis provide a sexually dimorphic GABAergic input to the anteroventral periventricular nucleus of the hypothalamus. Neuroscience 123: 793-803.

Poulin JF, Arbour D, Laforest S, Drolet G (2009). Neuroanatomical characterization of endogenous opioids in the bed nucleus of the stria terminalis. Prog Neuropsychopharmacol Biol Psychiatry 33: 1356-1365.

Rivier C, Rivest S (1991). Effect of stress on the activity of the hypothalamic-pituitary-gonadal axis: peripheral and central mechanisms. Biol Reprod 45: 523-532.

Sapolsky RM (1986). Stress-induced elevation of testosterone concentration in high ranking baboons: role of catecholamines. Endocrinology 118: 1630-1635.

Sawchenko PE, Swanson LW (1983). The organization of forebrain afferents to the paraventricular and supraoptic nuclei of the rat. J Comp Neurol 218: 121-144.

Searles RV, Yoo MJ, He JR, Shen WB, Selmanoff M (2000). Sex differences in GABA turnover and glutamic acid decarboxylase $(\mathrm{GAD}(65)$ and $\mathrm{GAD}(67))$ mRNA in the rat hypothalamus. Brain Res 878: 11-19.

Shughrue PJ, Lane MV, Merchenthaler I (1997). Comparative distribution of estrogen receptor-alpha and -beta mRNA in the rat central nervous system. J Comp Neurol 388: 507-525.

Simerly RB (1993). Distribution and regulation of steroid hormone receptor gene expression in the central nervous system. In: Seil FJ (ed). Advances in Neurology. Raven Press: New York. pp 207-225.

Simerly RB, Chang C, Muramatsu M, Swanson LW (1990). Distribution of androgen and estrogen receptor mRNA-containing cells in the rat brain: an in situ hybridization study. J Comp Neurol 294: 76-95.

Simerly RB, Young BJ, Capozza MA, Swanson LW (1989). Estrogen differentially regulates neuropeptide gene expression in a sexually dimorphic olfactory pathway. Proc Natl Acad Sci USA 86: 4766-4770.

Simmons DM, Arriza J, Swanson LW (1989). A complete protocol for in situ hybridization of messenger RNAs in brain and other tissues with radiolabeled single-stranded RNA probes. J Histotechnol 12: 169-181.

Singh R, Pervin S, Shryne J, Gorski R, Chaudhuri G (2000). Castration increases and androgens decrease nitric oxide synthase activity in the brain: physiologic implications. Proc Natl Acad Sci USA 97: 3672-3677.

Swanson LW (2004). Brain Maps: Structure of the Rat Brain. Academic Press: San Diego.

Swanson LW, Kuypers HG (1980). The paraventricular nucleus of the hypothalamus: cytoarchitectonic subdivisions and organization of projections to the pituitary, dorsal vagal complex, and spinal cord as demonstrated by retrograde fluorescence doublelabeling methods. J Comp Neurol 194: 555-570.

Viau V, Chu A, Soriano L, Dallman MF (1999). Independent and overlapping effects of corticosterone and testosterone on corticotropin-releasing hormone and arginine vasopressin mRNA expression in the paraventricular nucleus of the hypothalamus and stress-induced adrenocorticotropic hormone release. J Neurosci 19: 6684-6693.

Viau V, Lee P, Sampson J, Wu J (2003). A testicular influence on restraint-induced activation of medial parvocellular neurons in the paraventricular nucleus in the male rat. Endocrinology 144: 3067-3075.

Viau V, Meaney MJ (1991). Variations in the hypothalamicpituitary-adrenal response to stress during the estrous cycle in the rat. Endocrinology 129: 2503-2511.

Viau V, Meaney MJ (1996). The inhibitory effect of testosterone on hypothalamic-pituitary-adrenal responses to stress is mediated by the medial preoptic area. J Neurosci 16: 1866-1876. 
Viau V, Sawchenko PE (2002). Hypophysiotropic neurons of the paraventricular nucleus respond in spatially, temporally, and phenotypically differentiated manners to acute $v s$ repeated restraint stress: rapid publication. J Comp Neurol 445: 293-307.

Viau V, Soriano L, Dallman MF (2001). Androgens alter corticotropin releasing hormone and arginine vasopressin mRNA within forebrain sites known to regulate activity in the hypothalamic-pituitary-adrenal axis. J Neuroendocrinol 13: 442-452.

Williamson M, Bingham B, Gray M, Innala L, Viau V (2010). The medial preoptic nucleus integrates the central influences of testosterone on the paraventricular nucleus of the hypothalamus and its extended circuitries. J Neurosci 30: 11762-11770.

Williamson M, Bingham B, Viau V (2005). Central organization of androgen-sensitive pathways to the hypothalamic-pituitary- adrenal axis: implications for individual differences in responses to homeostatic threat and predisposition to disease. Prog Neuropsychopharmacol Biol Psychiatry 29: 1239-1248.

Williamson M, Viau V (2007). Androgen receptor expressing neurons that project to the paraventricular nucleus of the hypothalamus in the male rat. J Comp Neurol 503: 717-740.

Williamson M, Viau V (2008). Selective contributions of the medial preoptic nucleus to testosterone-dependant regulation of the paraventricular nucleus of the hypothalamus and the HPA axis. Am J Physiol Regul Integr Comp Physiol 295: R1020-R1030.

Zhao C, Fujinaga R, Tanaka M, Yanai A, Nakahama K, Shinoda K (2007). Region-specific expression and sex-steroidal regulation on aromatase and its mRNA in the male rat brain: immunohistochemical and in situ hybridization analyses. J Comp Neurol 500: $557-573$. 